J. Perinat. Med. 3 (1975) 198

\section{Time-limited phototherapy of term newborns in ABO hemolytic disease and hyperbilirubinaemia}

\author{
J. Rosta, Z. Makói, D. Békefi, E. Várady \\ Ist. Department of Pediatrics, Semmelweis University, Medical School \\ Budapest/Hungary (Head: Professor Dr. F. Gerlóczy)
}

Received September 12, 1974. Accepted December 2, 1974.
The National Academy of Sciences, USA [1], has published a preliminary report concerning the phototherapy of newborn infants. Despite 16 years of favorable experience with this "empirical therapeutic procedure" it was suggested that this therapy "to be kept to a minimum until more is known about its long-term effects". LUCEY [10] called for a more balanced approach. It has to be admitted, that there are no uniformly accepted indications for phototherapy at present and that its role in the prevention and treatment of neonatal jaundice is still not clear.

Earlier studies have reported on prophylactic light treatment of preterm babies when irradiation was started immediately after birth $[11,18]$. Later the $10 \mathrm{mg} / 100 \mathrm{ml}$ serum indirect bilirubin level was proposed as an indication $[5,6]$. Efficacy was assessed by the change in the means of daily serum bilirubin levels, compaired to controls and the frequency of the necessity in performing an exchange transfusion despite irradiation $[7,21]$.

\section{Purpose of the study}

At the Ist Department of Pediatrics, SEMmeLwEIs University Medical School, Budapest, a controlled clinical study was set up to find reasonable indications for the phototherapy of term newborns. In view of the controversy on long-term side effects $[3,9]$, irradiation was limited. Though an appropriate'spectroradiometer $[12,15]$ was not available, accurate registration

\section{Curriculum vitae}

Dr. J. RosTi graduated at the Budapest (now SEMMELWEIS) University Medical School in 1950. Since then working there at the Ist Department of $\mathrm{Pe}_{\mathrm{e}}$ diatrics and 2nd Department of Obstetrics, in the last 12 years as Head of the Neonatal Unit. Elected in 1964 as secretary, later first secretary of the Hungarian Pediatric Association. Editor of Hungarian and international journals and textbooks on neonatal medicine. Main research interest in jaundice of newborns. Thesis, more than 100 publications, papers given at international congresses and panels deal mostly with perinatal bilirubin metabolism and body composition.

of methodological details paved the way for future retrospective dosimetry.

\section{Material and methods}

Our material consisted of term babies with a birth weight above $2500 \mathrm{~g}$ (including 3 cases between 2350 and $2500 \mathrm{~g}$ ) and a gestational age over 37 completed weeks. Under such circumstances phototherapy was indicated only at a serum bilirubin value $4-6.0 \mathrm{mg} / 100 \mathrm{ml}$ lower than the critical level calling for exchange transfusion according to our previously designed diagram for the indication of exchange transfusion [17]. In both indicational programs separate limits were offered according 
to the various types of jaundice, intrauterine development, postnatal age and neurological findings (Fig. 1).

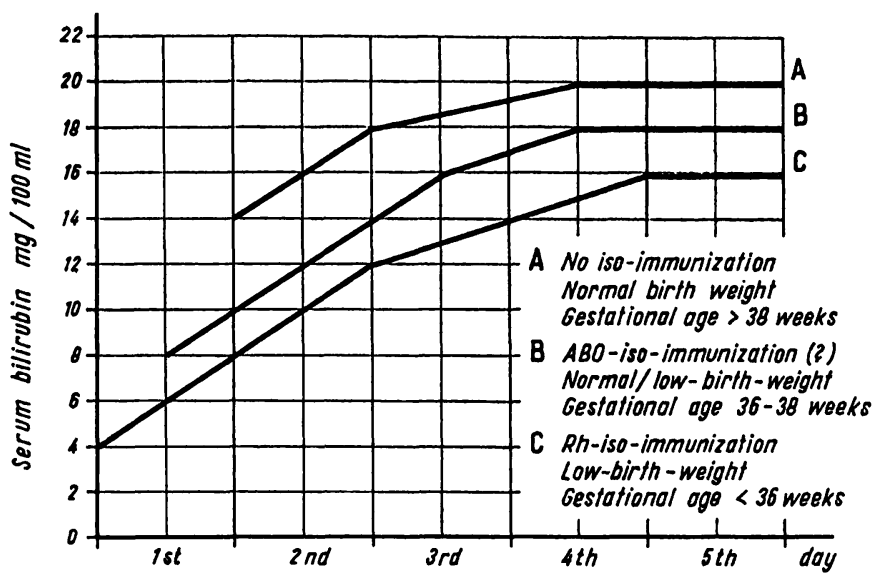

Fig. 1. Indications for phototherapy in term and near-term jaundiced infants.

The diagram covers the first five days of life as later irradiation was not initiated.

Our guide-lines were based on the hypothesis that they provide sufficient time for the light to exert its effect by reversing or at least decelerating bilirubin accumulation and reducing serum levels, whereby exchange transfusions can be avoided.

If a bilirubin level surpassed the limit for the indication of an exchange transfusion, phototherapy was considered inefficient and thus contraindicated. Light therapy was not used on febrile newborns, if septicemia or hepatitis was suspected or when metabolic disease was present. In such cases glucose-albumin infusions were preferred.

For phototherapy a MEDICOR KFL-21 instrument equipped with eight $20 \mathrm{~W}$ blue Tungsram lamps ( $450 \mathrm{~nm}$ wave-length peak emission) was used. The lamps were fixed $80 \mathrm{~cm}$ from the bed level. Ultraviolet waves (below $380 \mathrm{~nm}$ ) were shielded by a Plexiglas plate or by the top of the incubator [22]. The eyes of the infants were protected with thick gauze pads or dark glasses.

Irradiation was done for $\mathbf{1 8}$ hours daily consisting of three 6-hour periods with two-hour intervals until a marked drop in the serum indirect bilirubin level was noted. The change back and fro from prone to supine position, rectal temperature, bowel movements, voiding of urine, fluid intake (5\% glucose water) and any unusual events were recorded every hour on a flowsheet. Serum bilirubin levels were determined at least twice daily during irradiation and every 48 hours afterwards, to follow serum bilirubin concentrations.

During the first year of "limited" phototherapy (May 1, 1973 to May 1, 1974) 33 newborns were treated according to the above criteria. Their serologic and hematologic findings proved in 17 cases ABO-hemolytic disease, whereas 16 cases without any sign of hemolytic disease were grouped as "hyperbilirubinemia". Treatment of $\mathrm{Rh}$-hemolytic babies is not discussed in this paper.

Selected data of the patients and their treatment are given in Tab. I.

A control group of 44 comparable cases was gathered from newborns treated before May 1, 1973, along the same line, who did not receive phototherapy. The control babies were nearly identical in weight $( \pm 250 \mathrm{~g})$ and practically identical in serum bilirubin level $( \pm 1.0 \mathrm{mg}$ per $100 \mathrm{ml}$ ) with the treated ones at the point of time ( \pm 6 hours) when irradiation of the latter was begun.

\section{Results}

Exchange transfusion, based on identical indications in both periods before and after May, 1973, was necessary in 13 of the 44 babies treated without, and only 3 of the 33 infants treated with phototherapy (Tab. II). One of the unsuccessful cases proved to be a metabolic disease later.

Means and standard deviations of serum bilirubin levels are shown in Fig. 2-3.

The bilirubin levels of the treated babies were lower during the period of irradiation. This difference was significant on the second and third day of life, in the cases of ABO-hemolytic disease, and from 4th day of life in cases of hyperbilirubinemia, respectively. The lower values of the standard deviation in treated babies are particularly important, as the indication for exchange transfusion is related to this value.

Successful irradiation lasted in the average 44 hours (30-72 hours) in cases of ABO- 
Tab. I. Data of newborns subjected to phototherapy.

\begin{tabular}{|c|c|c|c|c|c|c|c|c|c|}
\hline \multirow{3}{*}{$\begin{array}{l}\text { Patient } \\
\text { No. } \\
1\end{array}$} & \multirow{3}{*}{$\begin{array}{c}\text { Sex } \\
\\
\mathrm{f}\end{array}$} & \multirow{3}{*}{$\begin{array}{c}\begin{array}{c}\text { Birthweight } \\
{[\mathrm{g}]}\end{array} \\
3200\end{array}$} & \multirow{2}{*}{\multicolumn{2}{|c|}{$\begin{array}{l}\text { Blood-group } \\
\text { mother/child }\end{array}$}} & \multirow{3}{*}{$\begin{array}{r}\begin{array}{c}\text { Onset } \\
\text { age } \\
\text { [hours] }\end{array} \\
28\end{array}$} & \multicolumn{3}{|c|}{ Phototherapy } & \multirow{3}{*}{$\frac{\text { Result* }}{\text { pos }}$} \\
\hline & & & & & & \multirow{2}{*}{$\begin{array}{c}\begin{array}{c}\text { Duration } \\
\text { [hours] }\end{array} \\
72\end{array}$} & \multicolumn{2}{|c|}{$\begin{array}{l}\text { Indirect serum } \\
\text { bilirubin level } \\
{[\mathrm{mg} / 100 \mathrm{ml}]} \\
\text { initial maximum } \\
\end{array}$} & \\
\hline & & & 0 & B & & & 16.5 & 20.5 & \\
\hline 2 & $\mathrm{~m}$ & 3100 & 0 & $A$ & 72 & 33 & 18.2 & idem & pos \\
\hline 3 & $f$ & 3800 & 0 & B & 24 & 42 & 13.6 & 18.0 & pos \\
\hline 4 & $\mathrm{f}$ & 2600 & 0 & $A$ & 50 & 30 & 17.0 & 17.6 & pos \\
\hline 5 & $f$ & 2350 gem & 0 & A & 96 & 42 & 21.2 & idem & pos \\
\hline 6 & $\mathrm{f}$ & 3200 & 0 & A & 16 & 30 & 15.2 & 23.5 & neg \\
\hline 7 & $\mathrm{~m}$ & 3600 & 0 & A & 72 & 32 & 20.0 & 20.8 & pos \\
\hline 8 & f & 2850 & 0 & A & 48 & 60 & 17.6 & 18.0 & pos \\
\hline 9 & $f$ & 2700 & 0 & A & 96 & 42 & 19.8 & 20.0 & pos \\
\hline 10 & f & 3500 & 0 & A & 81 & 33 & 21.4 & 22.5 & pos \\
\hline 11 & $\mathrm{f}$ & 3300 & 0 & A & 24 & 60 & 16.4 & 27.5 & neg \\
\hline 12 & $\mathrm{f}$ & 2900 & 0 & A & 48 & 50 & 15.8 & 23.4 & pos \\
\hline 13 & $f$ & 2700 & 0 & B & 28 & 30 & 14.2 & 14.4 & pos \\
\hline 14 & $\mathrm{~m}$ & 3100 & 0 & A & 24 & 48 & 10.8 & 18.6 & pos \\
\hline 15 & $\mathrm{~m}$ & 3300 & 0 & $\mathrm{~A}$ & 36 & 36 & 15.5 & idem & pos \\
\hline 16 & $\mathrm{~m}$ & 4100 & 0 & B & 48 & 48 & 18.4 & 21.4 & pos \\
\hline 17 & $\mathrm{~m}$ & 3150 & 0 & $B$ & 72 & 60 & 20.0 & 20.4 & pos \\
\hline 18 & $\mathrm{f}$ & 3100 & 0 & 0 & 116 & 34 & 20.8 & idem & pos \\
\hline 19 & $\mathrm{~m}$ & 3100 & 0 & 0 & 84 & 48 & 20.5 & 23.6 & pos \\
\hline 20 & $\mathrm{f}$ & 3300 & B & A & 96 & 30 & 23.0 & idem & pos \\
\hline 21 & $\mathrm{~m}$ & 2800 & A & A & 86 & 48 & 17.8 & 19.8 & pos \\
\hline 22 & $\mathrm{~m}$ & 3800 & B & 0 & 72 & 36 & 16.4 & 18.0 & pos \\
\hline 23 & $\mathrm{~m}$ & 3800 & $\mathrm{~A}$ & $\mathrm{~A}$ & 96 & 34 & 18.7 & idem & pos \\
\hline 24 & $\mathrm{~m}$ & 2800 & B & B & 96 & 18 & 17.0 & idem & pos \\
\hline 25 & f & 3650 & $\mathrm{AB}$ & $\mathrm{A}$ & 86 & 50 & 26.0 & idem & pos \\
\hline 26 & f & 2400 sfd & A & A & 74 & 30 & 18.5 & 20.0 & pos \\
\hline 27 & $\mathrm{f}$ & 2650 & A & $\mathrm{AB}$ & 50 & 30 & 19.0 & 20.0 & pos \\
\hline 28 & $\mathrm{f}$ & 2900 & B & B & 84 & 42 & 23.2 & 25.0 & pos \\
\hline 29 & $\mathrm{f}$ & 2350 sfd & $\mathrm{A}$ & 0 & 84 & 42 & 15.5 & 20.5 & pos \\
\hline 30 & $\mathrm{~m}$ & 2450 sfd & B & A & 96 & 48 & 18.5 & 19.0 & pos \\
\hline 31 & $\mathrm{~m}$ & 3150 & A & A & 50 & 66 & 16.8 & 23.0 & pos \\
\hline 32 & $\mathrm{~m}$ & 3500 & A & 0 & 84 & 42 & 21.5 & idem & pos \\
\hline 33 & $\mathrm{~m}$ & 2600 & 0 & 0 & 96 & 12 & 19.5 . & 24.5 & neg \\
\hline \multicolumn{10}{|c|}{ Comments: } \\
\hline Result*: & \multicolumn{9}{|c|}{$\begin{array}{l}\text { pos }=\text { according to }[17] \text { no exchange transfusion was necessary } \\
\text { neg }=\text { exchange transfusion was performed } \\
\text { gem }=\text { twin } \\
\text { sfd }=\text { small for dates infant, gestational age over } 37 \text { completed weeks }\end{array}$} \\
\hline
\end{tabular}

hemolytic disease and 40 hours (18-50 hours) in cases of idiopathic hyperbilirubinemia, respectively.

\section{Comment}

Indication for phototherapy in term infants is a controversial issue. The committee report, cited already in the introduction [1], suggested serum indirect bilirubin values below the $20 \mathrm{mg} / 100 \mathrm{ml}$ limit to be carefully considered before indicating irradiation in term babies. In a diagram plotted by A. BRown [2] and slightly modified by MAISELS [13] the following dye levels would invocate phototherapy: $5.0-9.0 \mathrm{mg} / 100 \mathrm{ml}$ on the first, $10.0-14.0 \mathrm{mg} / 100 \mathrm{ml}$ on the second, and $10.0-19.0 \mathrm{mg} / 100 \mathrm{ml}$ on the $3 \mathrm{rd}$ and 4 th day of life. According to this diagram the same indications are valid for babies with a birth weight below and above $2500 \mathrm{~g}$. Some more recent papers $[4,14]$ on the other hand take 
Tab. II. Number of exchange transfusions with and without phototherapy.
$\mathrm{ABO}$ hemolytic disease

with phototherapy

without phototherapy

(controls)

Hyperbilirubinemia

with phototherapy

without phototherapy

(controls)

\section{Number of Number of patients exchange transfusions}

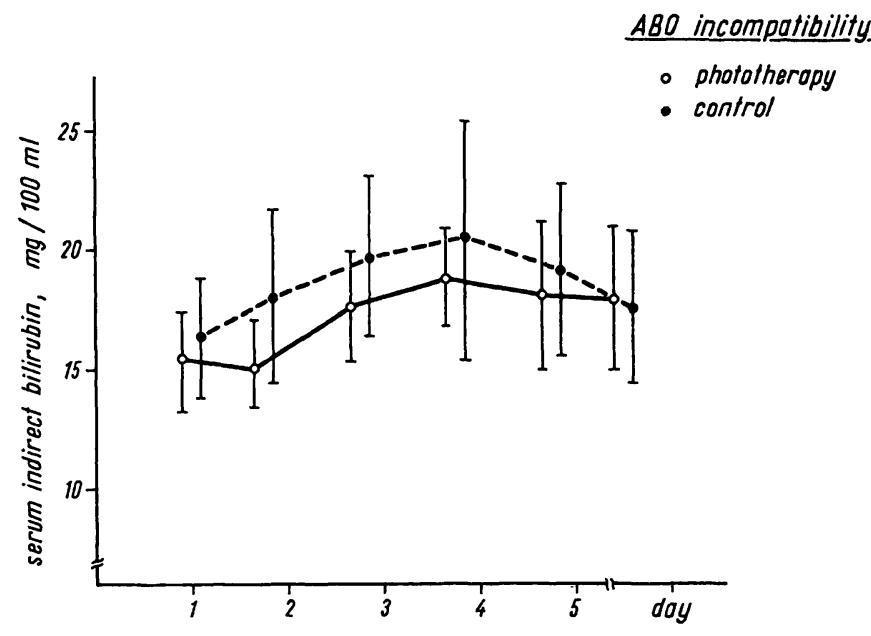

Fig. 2. Serum indirect bilirubin levels - means and $\pm 1 \mathrm{SD}$ - in ABO hemolytic disease with and without phototherapy.

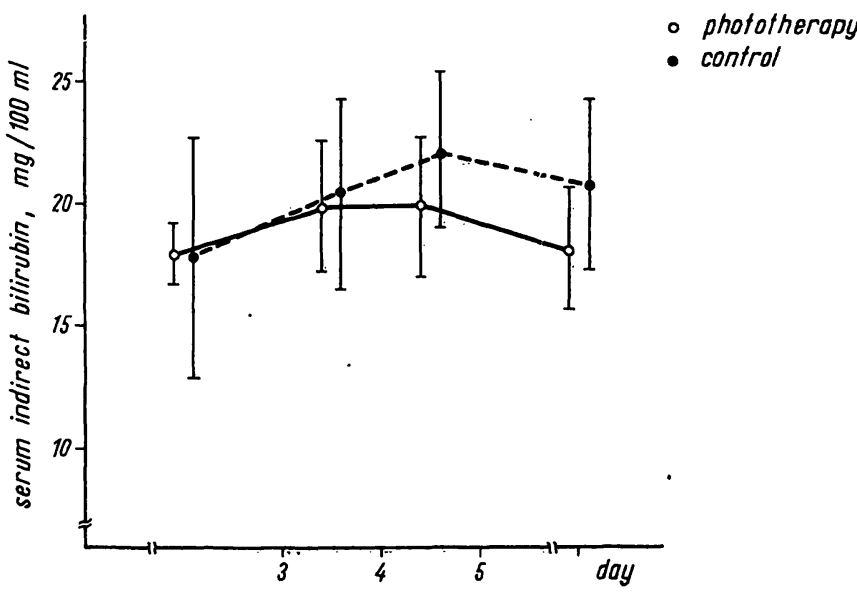

Fig. 3. Serum indirect bilirubin levels - means and $\pm 1 \mathrm{SD}$ - in cases of hyperbilirubinemia with and without phototherapy. phototherapy into consideration if serum bilirubin values fall into the intermediate zone on PoLACEK's diagram for indicating an exchange transfusion [16].

Our phototherapy diagram is similar to that of POLACEK and differs from Brown's by giving continuously rising limit-curves and not stepwise changing ones. The sudden rise of $5.0 \mathrm{mg} / 100 \mathrm{ml}$ at the end of each 24 hours of postnatal life makes BRown's diagram difficult to adapt to these special periods.

Another advantage of our diagram is the possibility of using separate guide-lines according to the etiology of jaundice and the gestational age (maturity) of the newborn infant. It has to be stressed, however, that babies not reaching their completed 35 weeks of gestation or weighing less than $2000 \mathrm{~g}$ have to be judged for phototherapy or exchange transfusion individually and according to another diagram.

In cases where the risk of kernicterus is high (if hypoxia, acidosis, hypothermia is present, or drugs competing for albumin binding sites were used), phototherapy should be begun at lower indicative values.

There are few papers dealing with phototherapy in ABO-hemolytic disease. Sisson et al. [19] and KAPLAN and coworkers [7] reported favorable results. Our experience confirms their observations.

TABB et al. were the first to suggest a timelimited phototherapy of $12-48$ hours to prevent hyperbilirubinemia in preterm infants [20]. We have attained a good effect with therapeutic irradiation of ABO-isoimmunized and hyperbilirubinemic term infants, when therapy was begun only at relatively high serum bilirubin levels. The originally proposed irradiation, lasting 144 hours seems excessive in term infants [8].

Short term phototherapy has two corner-stones: reserved indications and the lifting of irradiation as soon as an evident fall or harmless stagnation of bilirubin level is observed. We were never forced to resume phototherapy on account of a re-elevation of the bilirubin level, when the irradiation was once finished. 


\section{Summary}

"Limited" phototherapy was used to treat full term babies with and without ABO-isoimmunization. Serum indirect bilirubin levels calling for irradiation during the first five days of life are summarized in a diagram (Fig. 1). Separate indications were given for babies with different etiologies of jaundice, maturity (gestational age and birthweight) and indicational levels were correlated with the postnatal age (days and hours) of the infant.

After a fall or harmless stagnation of bilirubin levels irradiation was stopped.

Clinical assessment of the treatment of 17 babies with ABO-isoimmunization, and 16 newborns without it and with hyperbilirubinemia is given in detail (Tab. II and Figs. 2 and 3).

Results were compaired with the outcome of treatment of 44 newborns who received the same care in every respect, but phototherapy. These control cases, selected by pairs, were similar.

Exchange transfusion, based on identical indications, was necessary in 13 of the 44 babies treated without, and only 3 of the 33 infants treated with phototherapy. The bilirubin levels of the treated babies were lower during the whole course of the irradiation. The difference in favor of the treated babies was significant on the second and third days of life in cases of ABO-hemolytic disease, and from the 4th day of life in cases of hyperbilirubinemia. The values of standard deviations, important in view of the indication for exchange transfusion were also lower in the light treated babies.

Successful irradiation required on average of 44 hours (30-72 hours) in cases of ABO-isoimmunization and 40 hours (18-50 hours) in cases of hyperbilirubinemia, respectively. Re-elevation of the bilirubin level after finishing phototherapy was not observed.

Keywords: ABO-hemolytic disease, hyperbilirubinemia, neonatal jaundice, phototherapy.

\section{Zusammenfassung}

Zeitlich begrenzte Phototherapie bei reifen Neugeborenen (hämolytische Erkrankung im ABO-System und Hyperbilirubinämie)

Die zeitlich begrenzte Phototherapie wurde eingesetzt um am Termin geborene Kinder mit und ohne ABO-Isoimmunisierung zu behandeln. Die indirekten Serum-Bilirubinspiegel, welche für die Bestrahlung während der ersten 5 Lebenstage maßgeblich waren, sind in einem Diagramm zusammengefaßt (Fig. 1). Neugeborene mit Gelbsucht verschiedener Ätiologien wurden in getrennten Indikationsgruppen zusammengefaßt, desgleichen jene mit unterschiedlicher Reife, unterschiedlichem Gestationsalter und differentem Geburtsgewicht. Die Indikationsgruppen wurden zum postnatalen Alter des Neugeborenen (in Tagen und Stunden) korreliert.

Nach einem definitiven Abfall oder bei gefahrloser Konstanz der Bilirubinspiegel, wurde die Bestrahlung gestoppt.

Die klinischen Behandlungsresultate von 17 Neugeborenen mit ABO-Isoimmunisation und von 16 Neugeborenen ohne dieselbe jedoch mit Hyperbilirubinämie werden in Tab. II und Fig. 2 und 3 im Detail angegeben. Die Resultate wurden mit dem Behandlungsergebnis von
44 Neugeborenen verglichen, die in jeder Hinsicht dieselbe Behandlung erfahren haben mit Ausnahme der Phototherapie. Diese Kontrollfälle, welche paarweișe ausgeleșen wurden, waren ähnlich.

Eine Austauschtransfusion wurde bei ein und derselben Indikationsstellung in 13 Fällen der 44 Neugeborenen ohne und nur in 3 von 33 Kindern mit erfolgter Phototherapie notwendig. Die Bilirubinspiegel der bestrahlten Neugeborenen waren während der gesamten Bestrahlungsperiode niedriger. Die Differenz zugunsten der behandelten Neugeborenen war signifikant beim Vergleich des 2. und 3. Lebenstages bei den ABO-Inkompatibilitäten und des 4. Lebenstages bei den Fällen mit Hyperbilirubinämie. Die numerischen Werte der Standarddeviationen, die hinsichtlich der Indikationsstellung für die Austauschtransfusion wichtig sind, waren ebenfalls niedriger bei den mit Licht behandelten Neonaten.

Die erfolgreiche Bestrahlung belief sich im Mittel auf 44 Stunden (minimal 30, maximal 72 Stunden) bei den Fällen mit ABO-Isoimmunisation, auf 40 Stunden (18 bis 50 Stunden) bei Fällen mit Hyperbilirubinämie. Ein Wiederansteigen des Bilirubinspiegels nach Abschluß der Phototherapie wurde nicht beobachtet.

Schlüsselwörter: ABO-Inkompatibilität, Gelbsucht des Neonaten, Hyperbilirubinämie, Phototherapie.

\section{Résumé}

Photothérapie à temps limité des bébés nés à terme (maladie hémolytique $\mathbf{A B O}$ et hyperbilirubinémie) La photothérapie "limitée» a été utilisée pour traiter les bébés nés à terme avec et sans isoimmunisation ABO. Les taux de bilirubine indirecte du sérum indiquant la nécessité d'irradiation durant les cinq premiers jours après la naissance ont été classées dans un diagramme (Fig. 1). Des indications séparées ont été données pour les nouveaux-nés ayant des étiologies d'ictère différentes; maturité (âge de gestation et poids à la naissance) et les taux indicationnels ont été corrélationnés avec l'áge postnatal (jours et heures) de l'enfant. 
L'irradiation a été stoppéc après une baisse ou une stagnation non mauvaise des taux de bilirubine.

L'évaluation clinique du traitement de 17 bébés avec isoimmunisation $\mathrm{ABO}$ et de 16 nouveaux-nés sans isoimmunisation $\mathrm{ABO} /$ hyperbilirubinémie est donnéc de façon détaillée (Tab. II et Fig. 2 et 3 ).

Les résultats ont été comparés avcc l'issue du traitement de 44 nouveaux-nés ayant reçu les mémes soins moins la photothérapie. Ces cas de contrôle, sélectionnés par paires, étaient similaires.

La transfusion d'échange, basée sur des indications identiques, a été nécessaire chez 13 des 44 nouveaux-nés ayant été traités sans photothérapie et seulement chez 3 des 33 bébés traités avec photothérapie.
Les taux de bilirubine des bébés traités ont été moins élevés durant tout le temps de l'irradiation. La différence en favcur des bébés traités s'cst révélée significative les deuxic̀me ct troisicme jours après la naissance dans les cas de maladic hémolytique $\mathrm{ABO}$ et à partir du quatrième jour dans les cas d'hyperbilirubinćmie. Les valeurs des déviations standard, importantes pour l'indication d'une transfusion d'échange, ont donc été moins élevées chez les nouveaux-nés traités par photothérapic.

Une irradiation réussie fut durée respectivement à unc moyenne de 44 heures ( $30-72$ heures) dans les cas d'isoimmunisation $\mathrm{ABO}$ et de 40 heures (18-50 hcures) dans les cas d'hyperbilirubinémie. Aucune remontée du taux de bilirubine après photothérapie n'a été observece.

Mots-clés: Hyperbilirubinémie, ictère néonatal, maladic hémolytique $\mathrm{ABO}$, photothérapic.

\section{Bibliography}

[1] Behrman, R. E. et al.: Preliminary report of the committee on phototherapy in the newborn infant. J. Pediat. 84 (1974) 135

[2] BROwN, A. K.: Neonatal jaundice. In: BEHRMAN, R. E.: The diagnosis and treatment of diseases of the neonatal infant. Mosby, St. Louis 1973

[3] ENTE, G., S. W. KLEIN: Hazards of phototherapy. New Engl. J. Med. 283 (1970) 544

[4] Franke, P., H. C. Breyer, R. Hodr: Phototherapic bei Neugeborenen mit niedrigem Geburtsgewicht. Klin. Pädiat. 184 (1972) 461

[5] GIUNTA, F.: A 1 year experience with phototherapy for jaundice of prematurity. Pediatrics 47 (1971) 123

[6] Hsia, D. Y. Y., R. E. BeHrman: Summary of a symposium on phototherapy for hyperbilirubinemia. J. Pediat. 75 (1969) 718

[7] Kaplan, E., F. Herz, E. Scheye, L. D. Robinson Jr.: Phototherapy in ABO hemolytic disease of the newborn infant. J. Pediat. 79 (1971) 911

[8] LUCEY, J. F.: Neonatal jaundice and phototherapy. Pediat. Clin. N. Amer. 19 (1972) 827

[9] LuCEY, J. F.: The effect of light on the newly born infant. J. Perinat. Med. 1 (1973) 147

[10] LuCEY, J. F.: Another view of phototherapy. Comment. J. Pediat. 84 (1974) 14

[11] Lucey, J. F., M. Ferreio, J. Hewitr: Prevention of hyperbilirubinemia of prematurity by phototherapy. Pediatrics 41 (1968) 1047

[12] Lund, T. H., J. Gudum, W. Kop: The "blue" meter, a photometer designed to measure light emission during phototherapy of hyperbilirubinaemia. Acta paediat. scand. 63 (1974) 89

[13] Maiseds, M.: Bilirubin. Pediat. Clin. N. Amer. 19 (1972) 447
[14] Menzer, K., K. Schambach: Fototherapic bei ikterischen Neu- und Frühgeboernen. Dtsch. Gesundh. Wes. 29 (1974) 408

[15] Mrms, L. C., M. Estrada, D. S. Gooden, R. R. CaldwELL, R. V. KotAs: Phototherapy for neonatal hyperbilirubinemia - a dose response relationship. J. Pediat. 83 (1973) 658

[16] Polacek, K.: Unser Verfahren bei der Indikationsstellung zur Austauschtransfusion. Pädiat. Pädol. 1 (1965) 313

[17] Rosta, J., D. BÉKerr: A new chart for indicating exchange transfusion in neonatal hyperbilirubinaemia. Acta paediat. Acad. Sci. hung. 12 (1971) 311

[18] Schwarz, A., J. E. Hodgman: Phototherapy and hyperbilirubinemia of the premature. Amer. J. Dis. Child. 119 (1970) 473

[19] Sisson, T. R. C., N. Kendall, S. C. Glauser, S. KNUt'son, E. Bunyarovich: Phototherapy of jaundice in newborn infants. I. ABO blood group incompatibility. J. Pediat. 79 (1971) 904

[20] Tabb, P. A., D. C. L. Savage, J. Inglis, C. H. M. WALKER: Controlled trial of phototherapy of limited duration in the treatment of physiological hyperbilirubinaemia in low-birth-weight infants. Lancet II (1972) 1211

[21] Wong, Y. K., B. S. B. Wood: Relative roles of phototherapy and phenobarbitone in treatment of nonhaemolytic neonatal jaundice. Arch. Dis. Childh. 48 (1973) 704

[22] Yasunaga, S., E. H. Kean: The effect of plexiglas incubators on phototherapy. J. Pediatr. 81 (1972) 89
Dr. J. Rosta Ullöi-ut 78/a 1083-Budapest/Hungary 